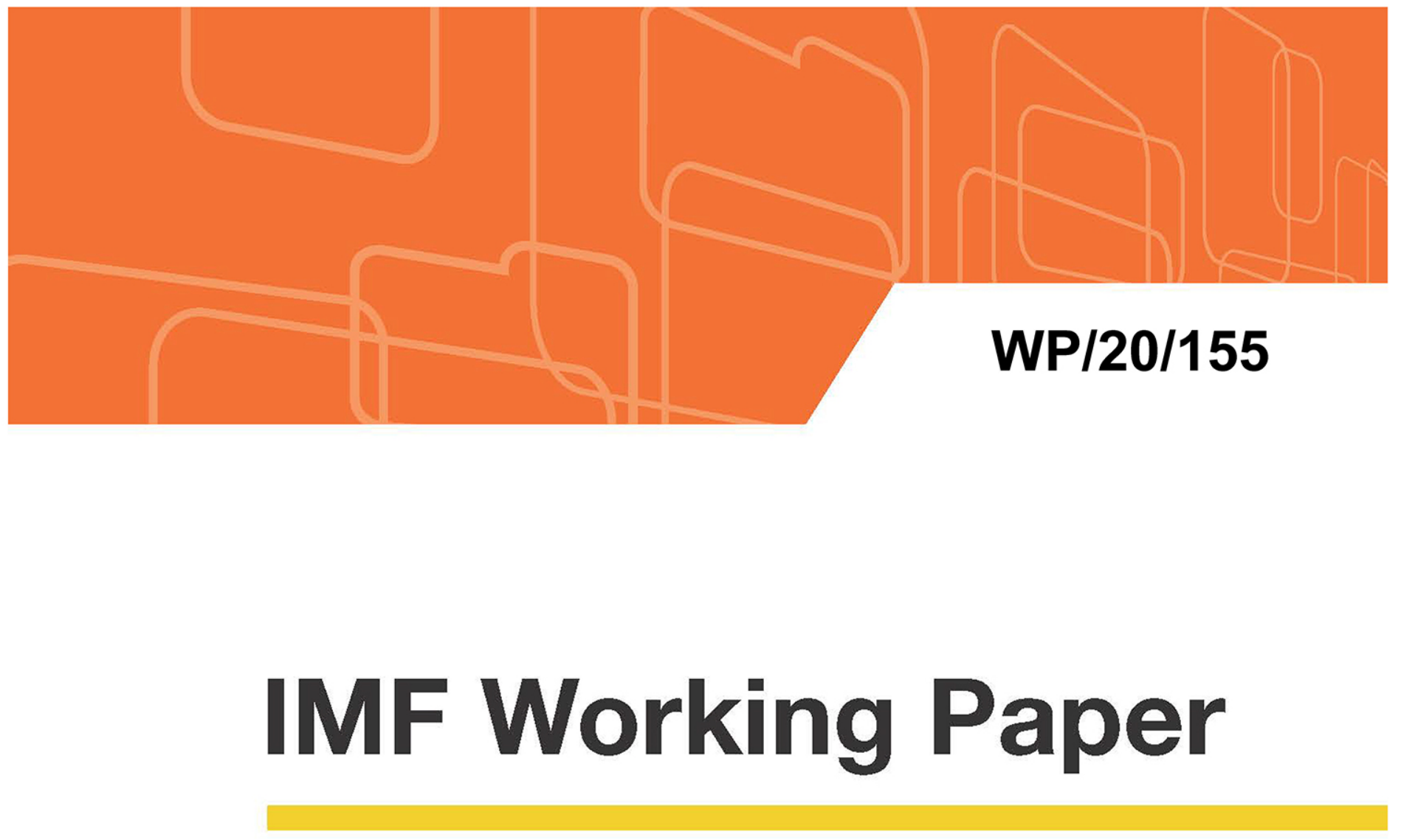

\title{
Productivity in the Netherlands
}

by Sakai Ando

IMF Working Papers describe research in progress by the author(s) and are published to elicit comments and to encourage debate. The views expressed in IMF Working Papers are those of the author(s) and do not necessarily represent the views of the IMF, its Executive Board, or IMF management.

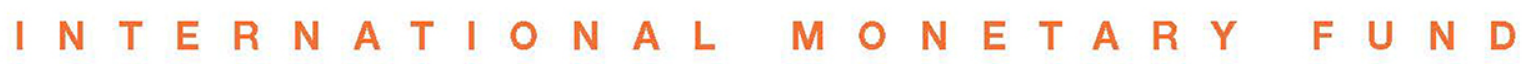




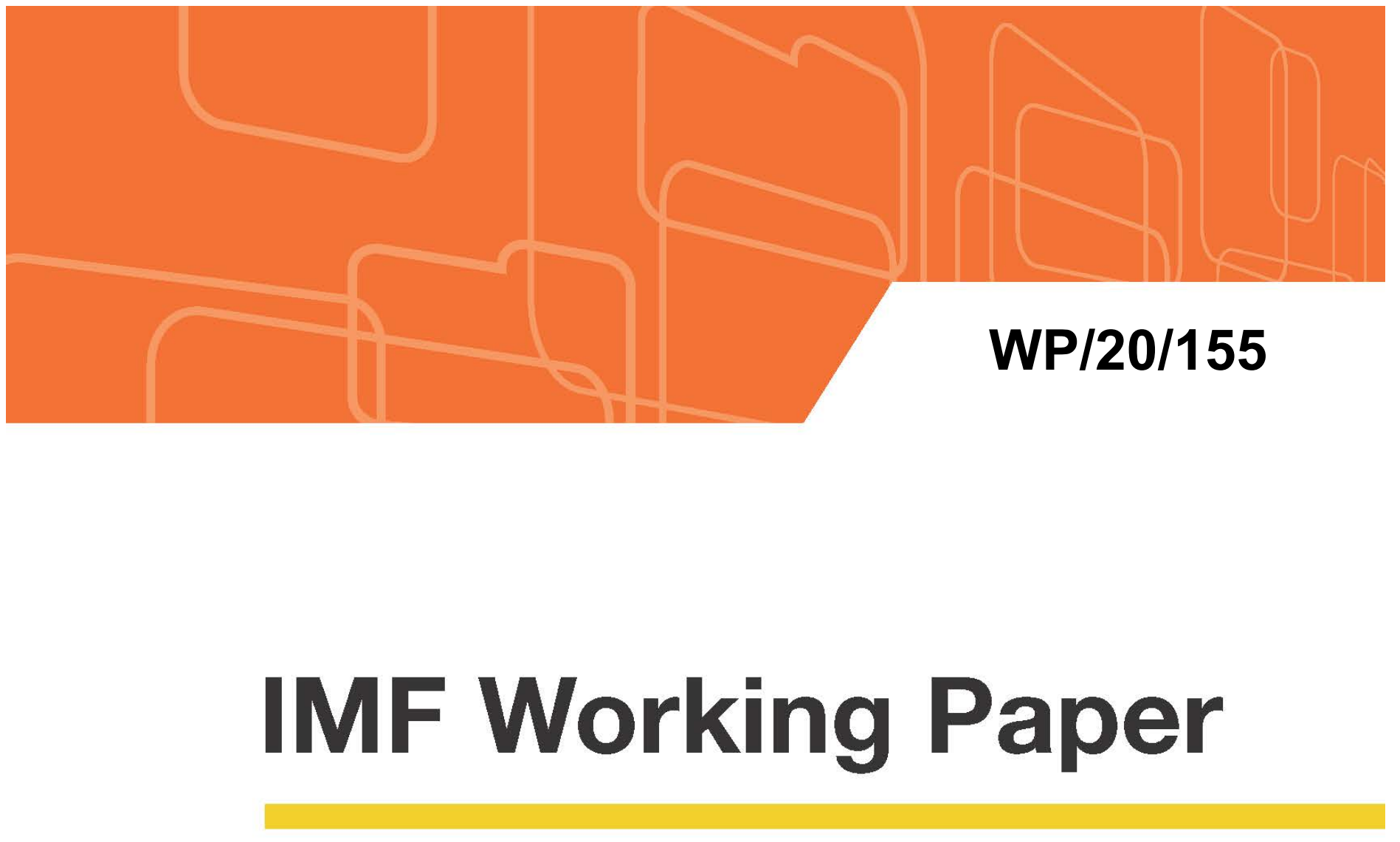

\section{Productivity in the Netherlands}

by Sakai Ando

IMF Working Papers describe research in progress by the author(s) and are published to elicit comments and to encourage debate. The views expressed in IMF Working Papers are those of the author(s) and do not necessarily represent the views of the IMF, its Executive Board, or IMF management.

I N T E R N A T I O N A L M O NETAR Y F U N D 


\title{
IMF Working Paper
}

\author{
European Department
}

\section{Productivity in the Netherlands \\ Prepared by Ando Sakai}

Authorized for distribution by Alfredo Cuevas

August 2020

Disclaimer: This document was prepared before COVID-19 became a global pandemic and resulted in unprecedented economic strains. It, therefore, does not reflect the implications of these developments and related policy priorities. We direct you to the IMF Covid-19 page that includes staff recommendations with regard to the COVID-19 global outbreak.

IMF Working Papers describe research in progress by the author(s) and are published to elicit comments and to encourage debate. The views expressed in IMF Working Papers are those of the author(s) and do not necessarily represent the views of the IMF, its Executive Board, or IMF management.

\begin{abstract}
Although GDP growth in the Netherlands has recently been stronger than in peer countries, the main contributor has been the growth in labor. If GDP is divided by labor, productivity growth appears to have been slower than in peers. This chapter discusses both exogenous and endogenous factors behind the disappointing productivity growth in the Netherlands and derives policy implications.
\end{abstract}

JEL Classification Numbers: D24, E24, J21, J24, O47

Keywords: productivity, labor-market duality

Author's E-Mail Address: sando@imf.org 
TABLE OF CONTENTS

ABSTRACT

I. INTRODUCTION $\underline{4}$

II. LABOR $\underline{5}$

III. CAPITAL $\underline{8}$

IV. MFP AND POLICY ACTIONS 10

V. CONCLUSION 13

VI. REFERENCES $\underline{16}$

APPENDIX

DESCRIPTION OF SECTOR LABELS $\underline{15}$ 


\section{INTRODUCTION}

1. The growth of the Netherlands' GDP has been stronger than in peer countries since 2016. The annual real GDP growth in the Netherlands from 2016 to 2018 was on average 2.5 percent, while the average in the euro area was 2.2 percent and for $\mathrm{G} 7$ countries was 2.0 percent.

\section{The main contributor to strong real} GDP growth in the Netherlands has been labor input growth. Growth accounting analysis shows that more than 60 percent of real GDP growth can be attributed to the labor input, while ICT (information and communications technology) and non-ICT capital combined account for only 15 percent.

\section{If GDP is divided by labor input,} productivity growth in the Netherlands has been slower than in peers. The annual growth rate of real GDP per hour worked was on average 0.4 percent, less than half of the 0.9 percent for the euro area and 0.8 percent for G7 countries. The qualitative result remains the same if the productivity is instead measured by GDP per person employed.

\section{Productivity in the Dutch economy has} been studied from different perspectives. A non-exhaustive list of the literature on the Netherlands's productivity slowdown includes Grabska et al. (2017), who argue that the slowdown in the 2010s may consist of a return to a normal growth rate after the ICT boom in the late 1990s. Bondt (2019) appeals to the increase in the self-employed persons. Jonkers (2019) highlights the increase in total hours worked
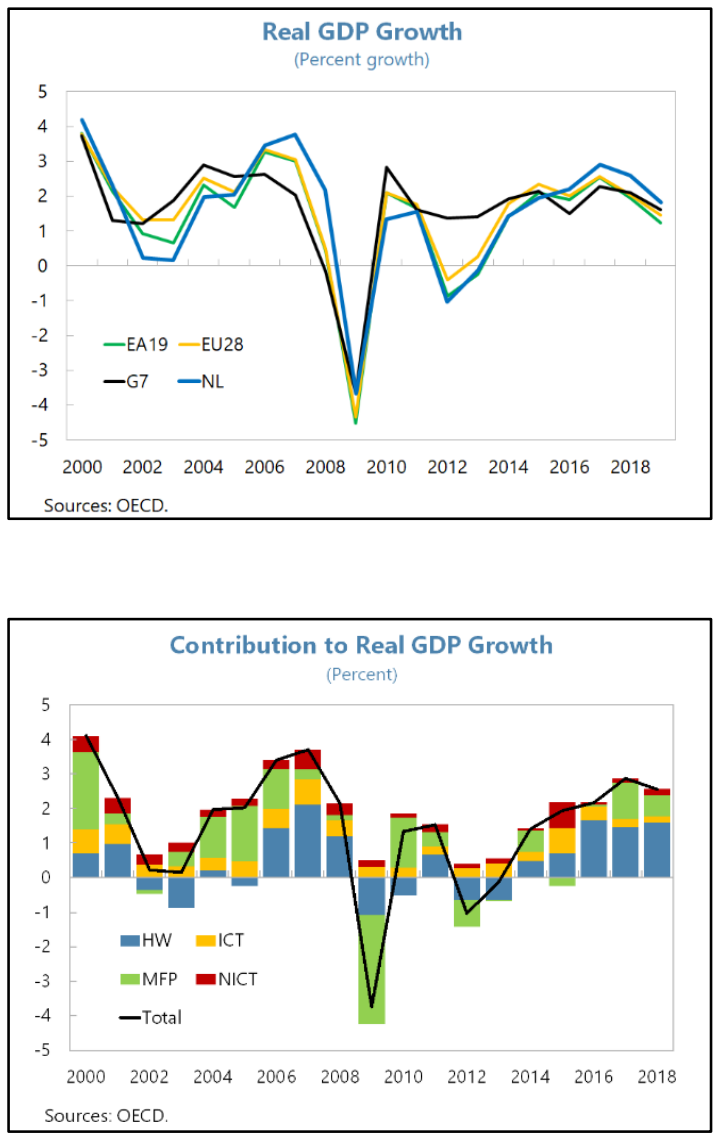
despite the aging population, and Bun and Winter (2019) explore the increasing capital misallocation arising from a combination of small productive and large unproductive firms.

\section{This chapter explores the potential "culprits" of the productivity slowdown of} the last decade by looking into each input category and concludes with policy implications. The labor and capital sections analyze the behavior of equilibrium objects in 
the labor and capital input, while the section of MFP (multifactor productivity) and policy actions includes the analysis of the government policies that could impact long-term productivity.

\section{LABOR}

\section{Aggregate labor productivity growth can be decomposed into within-sector} labor productivity growth and structural change in each sector's labor share in total employment. To analyze the change in aggregate productivity from the perspective of the labor market, it is useful to apply the following decomposition.

$$
\frac{V_{t}}{L_{t}}-\frac{V_{t-k}}{L_{t-k}}=\sum_{s}\{\underbrace{\frac{L_{s, t-k}}{L_{t-k}}\left(\frac{V_{s t}}{L_{s t}}-\frac{V_{s, t-k}}{L_{s, t-k}}\right)}_{\text {productivity growth }}+\underbrace{\left(\frac{V_{s t}}{L_{s t}}-\frac{V_{t}}{L_{t}}\right)\left(\frac{L_{s t}}{L_{t}}-\frac{L_{s, t-k}}{L_{t-k}}\right)}_{\text {structural change }}\},
$$

where $V_{t}$ and $L_{t}$ are the sectoral sum of gross value added and labor at time $t$

$$
V_{t}:=\sum_{s} V_{s t}, \quad L_{t}:=\sum_{s} L_{s t} .
$$

Note that (1) the productivity growth within each sector is weighted or amplified by the size of the sector, as measured by its labor share, and (2) a positive structural change happens to a sector if the sector's size measured by its labor share increases (falls) and the sector's productivity is higher (lower) than the average productivity. If the signs of the two multiplicative terms are, instead, different, a negative structural change is recorded.

\section{Both the aggregate labor productivity} growth and structural change have slowed down. The aggregate labor productivity growth from 2015 to 2018 was on average 0.9 percent, while it was on average 1.4 percent before 2014, excluding 2009 and $2010 .{ }^{1}$ The aggregate structural change for the corresponding periods was -0.6 and -0.1 percent respectively. The rest of the section analyses in detail the labor productivity growth using the decomposition

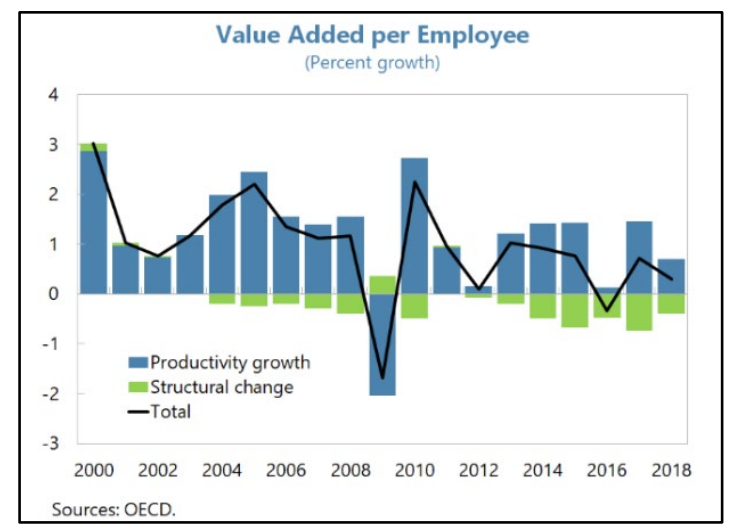
proposed above.

\footnotetext{
${ }^{1}$ The exclusion of 2009 is to remove the Global Financial Crisis. The exclusion of 2010 is to remove the base effect from 2009. Inclusion of 2009 and 2010 does not change the qualitative result.
} 


\section{A significant negative structural} change occurred in the finance, mining, and administrative support sectors. ${ }^{2}$ Firstly, highproductivity sectors such as mining and finance, and to a lesser extent real estate and manufacturing, reduced their shares in total employment. And secondly, expansion took place in low-productivity sectors such as administrative support, and to a lesser extent in accommodation and food. Below are some of the sector-specific developments observed in the three sectors.

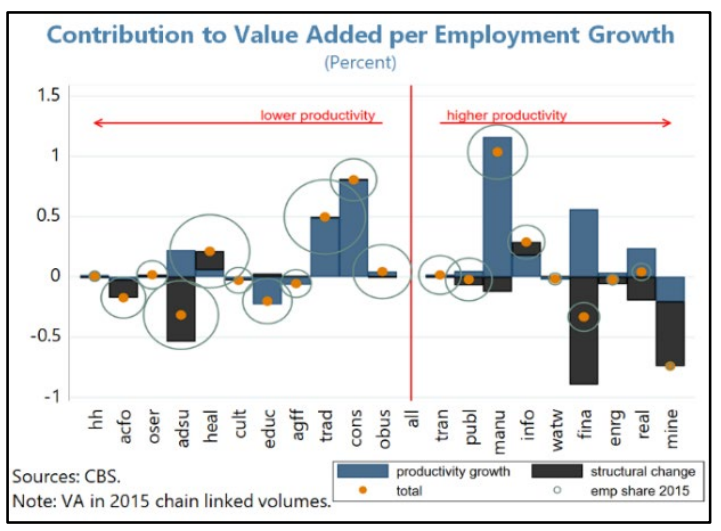

- Financial service activities except insurance and pension funds: banks are the major players in this sector and have suffered from declining value-added since the Global Financial Crisis due to factors including the low interest rate and competition with fintech. Digitalization also contributes to the shift of needed skill sets. These developments led to the decline of employment by on average 4.5 percent annually since 2013.

- Mining and quarrying: the oil price decline since 2014 has reduced the value-added of the sector. The planned closure of the Groningen gas field due to the induced earthquakes accelerated the shrinkage of employment there. The political pressure on the government rose after the 2012 earthquake and the decision was made after the 2018 earthquake. The employment decline was 20 percent in 2017.

- Employment activities: placement, temporary staffing, and human resource services have been the driving force behind the growth of employment in the administrative support sector since 2013. The average annual employment growth rate in these activities since then was 7.8 percent, far above the 1.4 percent for the total economy. Behind the expansion could be both demand factors such as more outsourcing due to the routinization of tasks and supply factors including technological advancement in job matching. Indeed, some of the largest human resource companies in the world are located in the Netherlands. The supply of the labor force could come from both extensive and intensive margins. In the extensive margin, the labor participation rate has been rising from 72.4 in 2014Q1 to 78.4 percent in 2019Q3. The employees from abroad also rose by 20 percent from 2013 to 2017 . The supply of labor could also come from the intensive margin, including some of the high productivity sectors due to labor-saving technological changes there.

\footnotetext{
${ }^{2}$ See Appendix I for the description of sector labels in the chart.
} 


\section{Note that the analysis of the sectoral decomposition only captures the actual} structural change and does not necessarily capture the pressure on structural change. For example, the construction sector has experienced a severe staff shortage amid the ongoing housing boom. As of 2018, nearly 40 percent of entrepreneurs in the construction sector report staff shortage, which is the highest among all sectors where the corresponding number is 25 percent. ${ }^{3}$ Similarly, staff shortages due to skill mismatches are reported in some of the high productivity sectors. ${ }^{4}$ Since the employment growth does not catch up with the aggregate demand in those sectors, such pressure on structural change is partly reflected in the sectoral productivity growth.

10. In addition to the structural change, sectoral productivity growth has also been weak. One factor that this chapter explores is the high prevalence in the labor force of flexible work arrangements (FWA) such as part-time employees and self-employed. More than 50 percent of the Netherlands' labor force is part-time, working less than 35 hours per week. ${ }^{5}$ The share of self-employment is also high compared to peer countries.
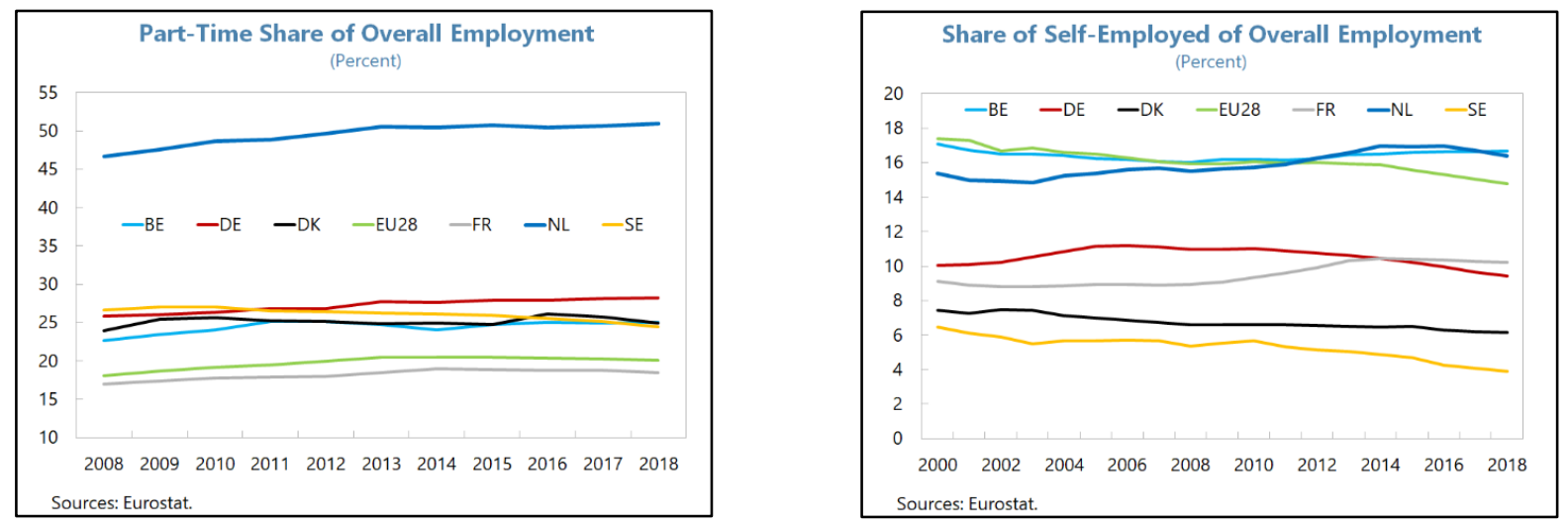

\section{The empirical relationship between the share of workers in FWA and}

productivity is negative. The sectors with a higher share of part-time workers tend to exhibit lower productivity levels and growth. The same pattern can be observed for selfemployment.

\footnotetext{
${ }^{3}$ See CBS (2018).

${ }^{4}$ See European Commission (2016).

${ }^{5}$ The definition of part-time employment might differ across countries. Under the definition of working less than 30 hours per week used by OECD, the Netherlands still exhibits the highest part-time employment rate in the world.
} 

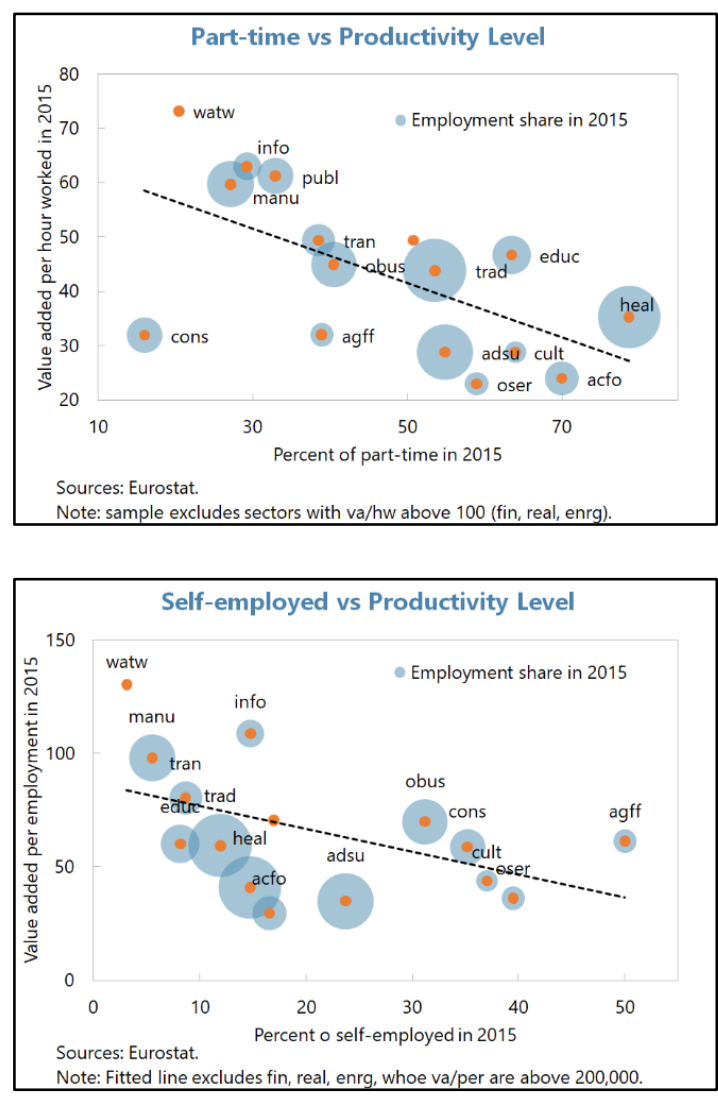
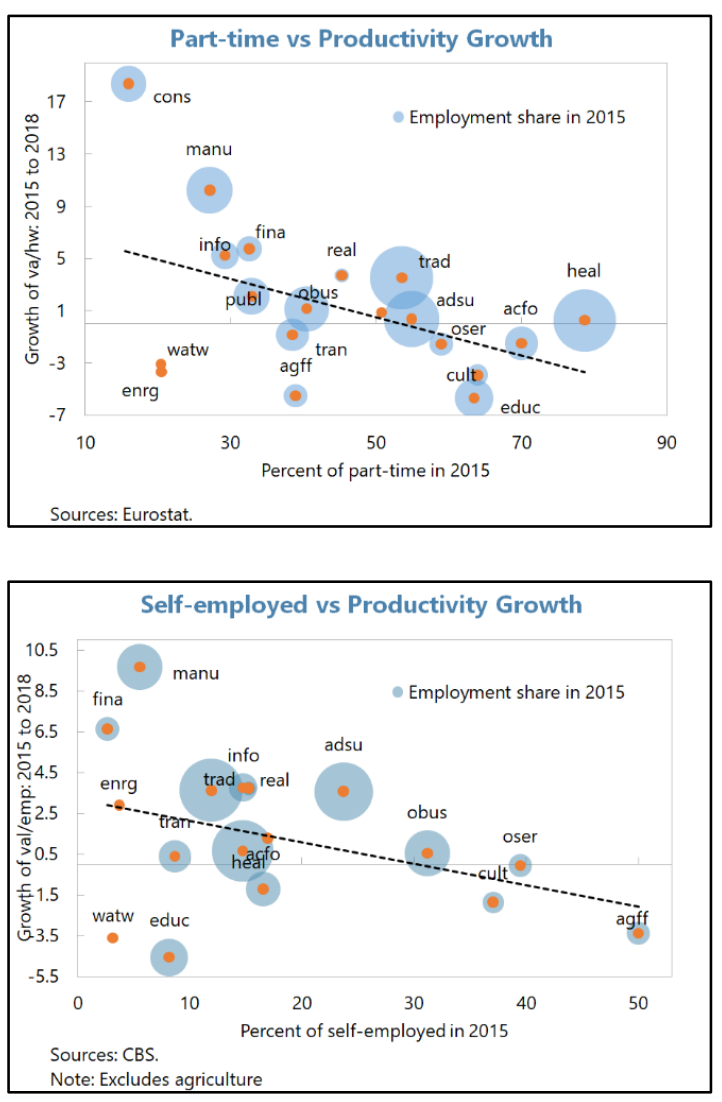

12. One story consistent with the negative relationship is that the firms with lower productivity access cost-competitive workers in FWA more than the firms with higher productivity. On the one hand, the availability of the cost-competitive workers in FWA contributes to employment opportunities. One the other hand, the reliance on the costcompetitive workers in FWA might reduce the incentive for firms to enhance productivity.

\section{Capital}

13. In contrast to the labor input, the contribution of capital to GDP growth has been decreasing over time and is smaller than in peer countries. The average contribution of ICT and non-ICT capital combined between 2016 and 2018 was 15 percent, although it had been 43 percent before 2015 excluding 2009 and $2010 .{ }^{6}$ The concentration on the labor input stands out when compared with peer countries in

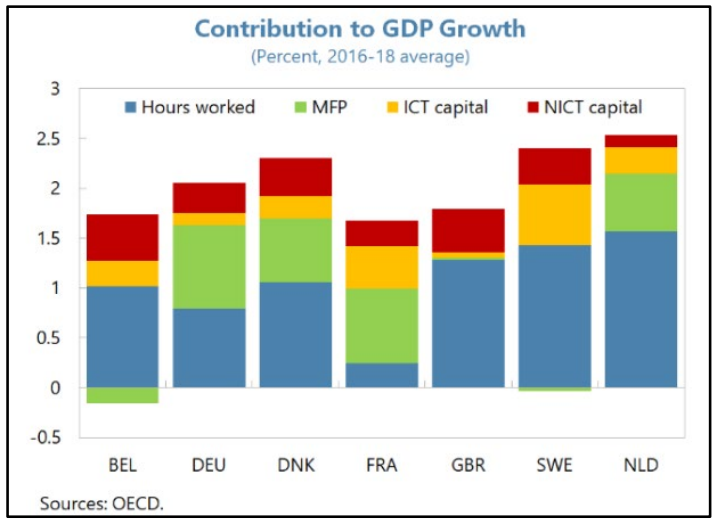

\footnotetext{
${ }^{6}$ If 2009 and 2010 are included, the contribution becomes 55 percent.
} 
Europe. To understand the main driver, this section divides ICT and non-ICT capital into subcomponents.

\section{ICT computer hardware and} telecommunications equipment, non-ICT R\&D and machinery contribute less to GDP growth in the Netherlands than in peer countries. In the latest data, for 2017, a year for which comparable data are available for all the seven peers, nearly 85 percent of the Netherlands ICT capital investment was through computer software and databases. The contribution of $\mathrm{R} \& \mathrm{D}$, other intellectual properties and other machinery to the non-ICT capital investment was all negative.

\section{The nature of the weak investment} may be more structural than cyclical. The time-series data suggest that the decline in computer hardware follows a decreasing trend.
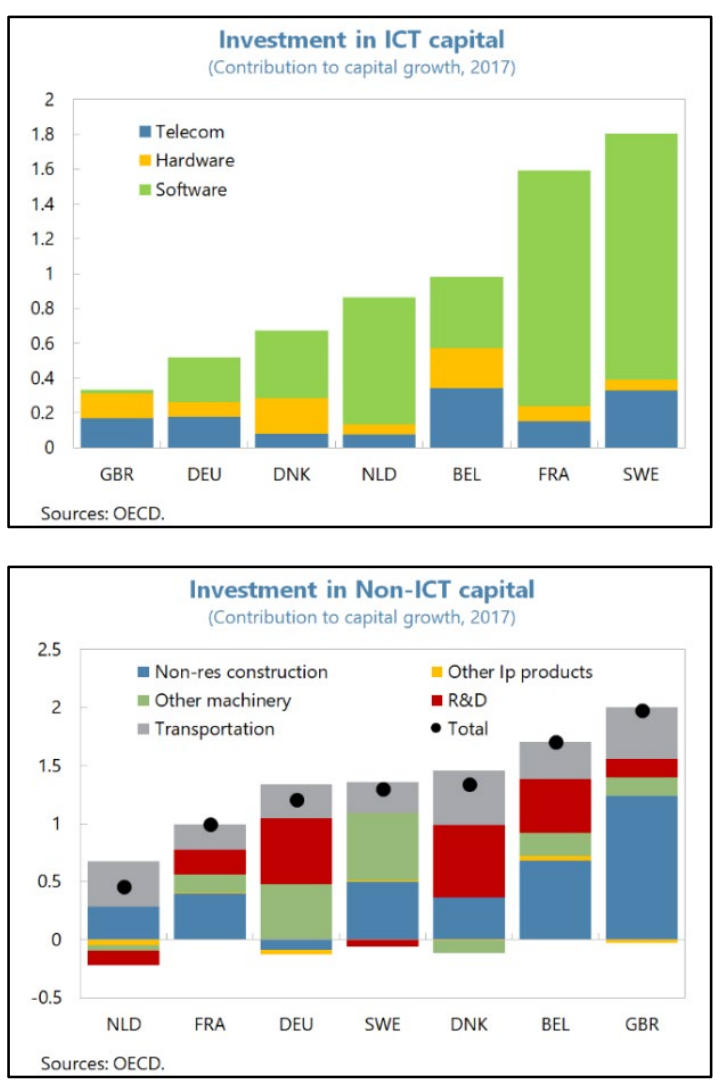

R\&D has also been weaker since 2008 except for a jump in 2015 caused by a transaction made by a multinational firm in the administrative support sector. Weak investment in other machinery and equipment and weapons systems has also been observed since the Global Financial Crisis. Thus, the weak investment seems to be a long-term structural problem instead of a cyclical phenomenon.
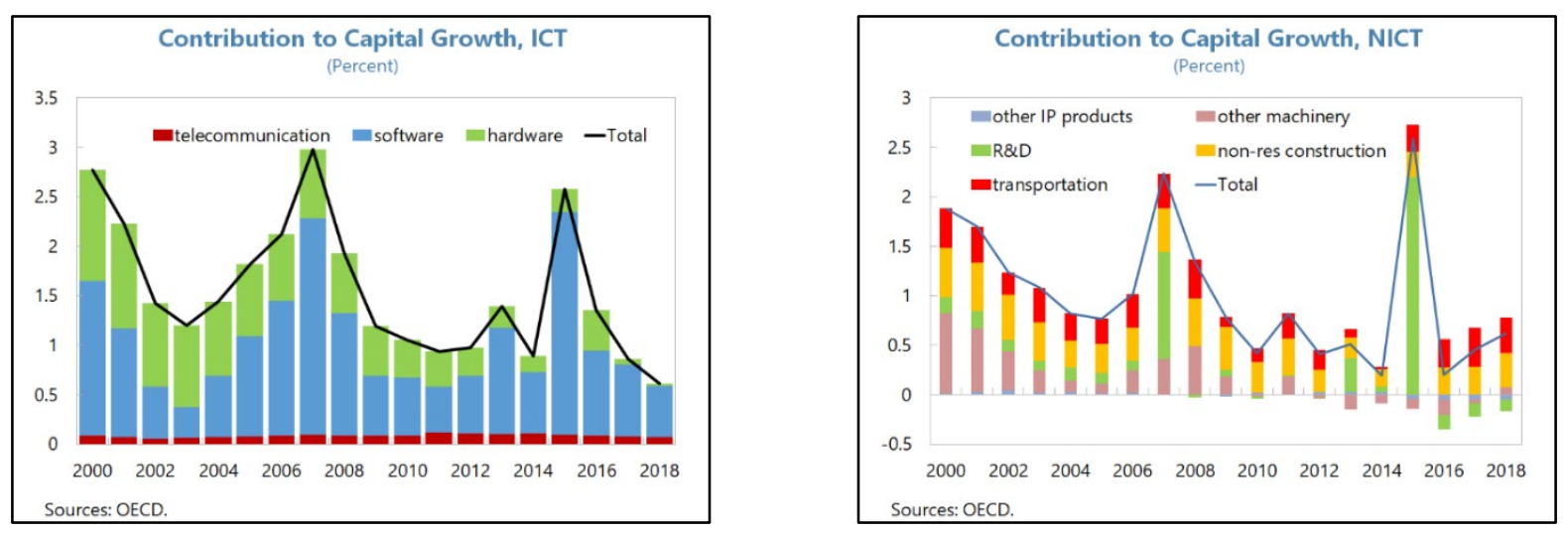

\section{The sectors with lower investment tend to exhibit lower productivity levels and} growth in the long run. Although the direction of the causality is indeterminate, the positive correlation is consistent with the story that low investment in low-productivity sectors is one of the factors behind the slow productivity growth. 

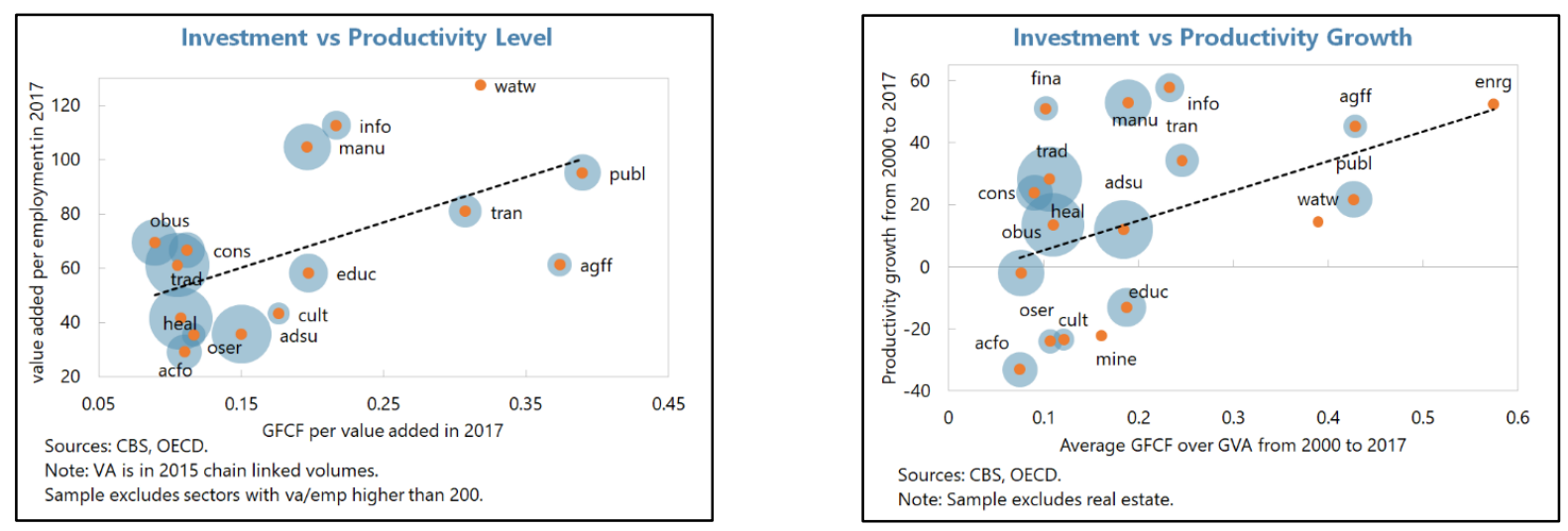

17. In connection with the labor market, the sectors with a higher share of workers in FWA tend to exhibit lower investment in capital. Such correlation is consistent with the story that firms in lower-productivity sectors tend to rely more on cost-competitive workers in FWA and have less incentive to invest in productivity-enhancing capital.
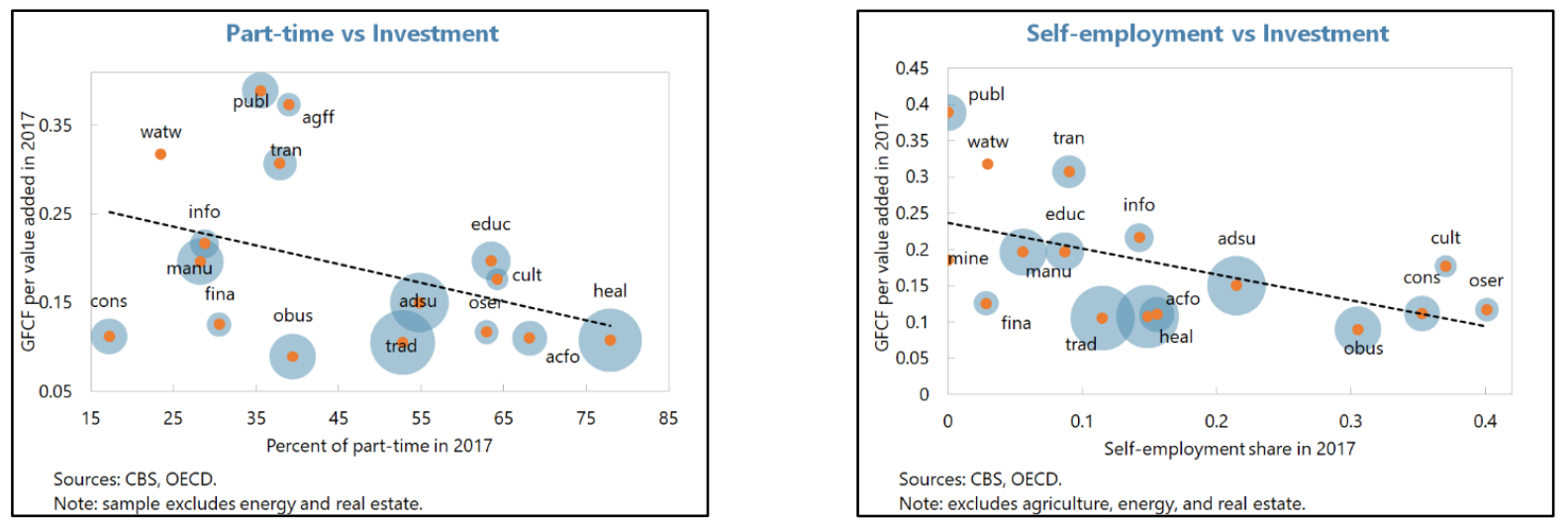

\section{MFP AND Policy ACTions}

18. Multi-factor productivity (MFP) is the part of GDP growth that is not explained by the measured growth of labor and capital inputs. Being a residual, it is affected by methodological decisions concerning the measurement of labor and capital. For example, unmeasured labor input, such as effort intensity, ends up reflected in MFP. The fact that the sign of MFP often coincides with that of the labor input suggests that a part of MFP captures such unmeasured labor input. Similarly, the unmeasured capital input including capital utilization rates is reflected in MFP. Other factors captured by MFP that originate from labor and capital include:

- Skill mismatches and education attainment: the shortage of ICT talent has been reported to be one of the mismatch priorities. In 2018, more firms than in peer countries tried to recruit ICT talent (13 percent in the Netherlands vs 9 percent in the euro area), and the Netherlands had a higher percentage of firms with hard-to-fill ICT vacancies (69 vs 
53 percent respectively). The share of workers with tertiary level ICT education is also below the average in the euro area (58 percent in the Netherlands vs 73 percent in the euro area). Removing these frictions can raise MFP through the increase in human capital.

- Dwellings and cultivated biological resources: these types of fixed assets are not included in the measure of capital according to the methodology of the OECD. ${ }^{7}$ This may have varying effects over time. On the one hand, the increase in housing supply, which affects GDP growth but does not affect capital stock, shows up as an increase in MFP. On the other hand, the mass decline in the gross fixed capital formation of livestock from 346 million euros in 2016 to 31 million euros in 2018 due to the phosphate reduction plan agreed with the EU will show up as a future decrease in MFP through output decline in relevant sectors. Although the net effect is not observable under growth accounting, it is useful to understand how these measurement conventions can, in combination with real developments, lead estimated MFP to fluctuate.

19. Policy is one of the most important factors reflected in MFP because any policy that affects GDP growth but does not immediately change labor and capital inputs ends up captured in MFP. For example, the December 2019 Supreme Court decision ordering the government to cut the nation's greenhouse gas emissions by 25 percent from 1990 levels by the end of 2020 can potentially have a large impact on MFP depending on the way this order is implemented. ${ }^{8}$ The rest of the section describes three policy areas that affect longterm productivity growth.

20. First, public expenditure on education is in the middle range among peers but grows more slowly than GDP in primary and "other" education. The expenditure made by the general government on education was 5.1 percent of GDP in 2018. Although this number is higher than those in the United Kingdom and Germany, the Netherlands is behind other advanced economies such as Denmark and Sweden. The expenditure has grown more slowly in primary education and other education categories, while it has been more or less flat in secondary and tertiary education. Given that some of the human capital such as ICT skills can be facilitated by both early-stage immersion and vocational training, a more balanced education system that supplies needed human capital will contribute to long-term

\footnotetext{
${ }^{7}$ See chapter 8 of OECD (2019) for the methodology.

${ }^{8}$ Ministry of Health, Welfare and Sport (2019) reports that, in 2017, the total greenhouse gas emissions were 12.6 percent below the emissions in the base year 1990 .
} 
productivity growth through the reduction of skill mismatches and accumulation of human capital.
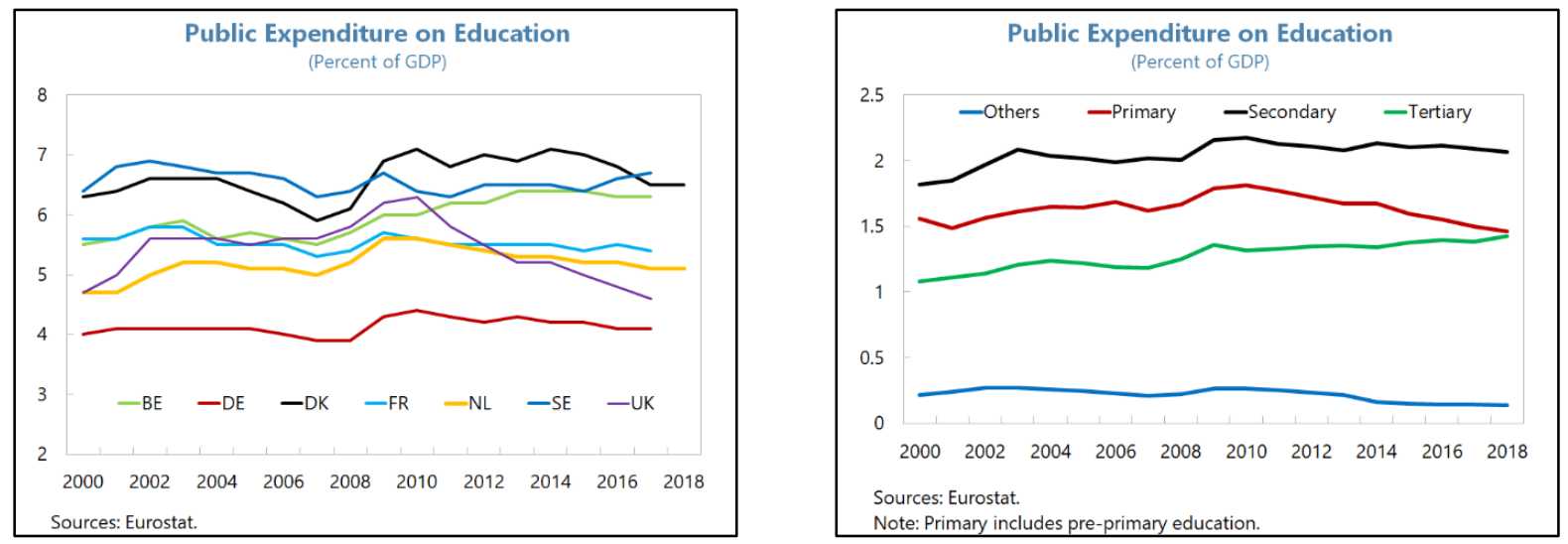

21. Second, public expenditure on $R \& D$ is in the middle range among peers but concentrates on health and economic affairs. The general government expenditure on R\&D in 2017 was 1.5 percent, which is lower than in other innovation frontiers such as Denmark (2 percent) and Sweden (1.8 percent). The further decomposition shows that the public expenditure on R\&D concentrates in health and economic affairs. ${ }^{9}$ In contrast, the public expenditure on basic research that supports research institutes and universities is onethird of Denmark and Sweden in percent of GDP. A more balanced R\&D support that sustains innovation can contribute to long-term productivity growth through positive spillovers of knowledge and technology.
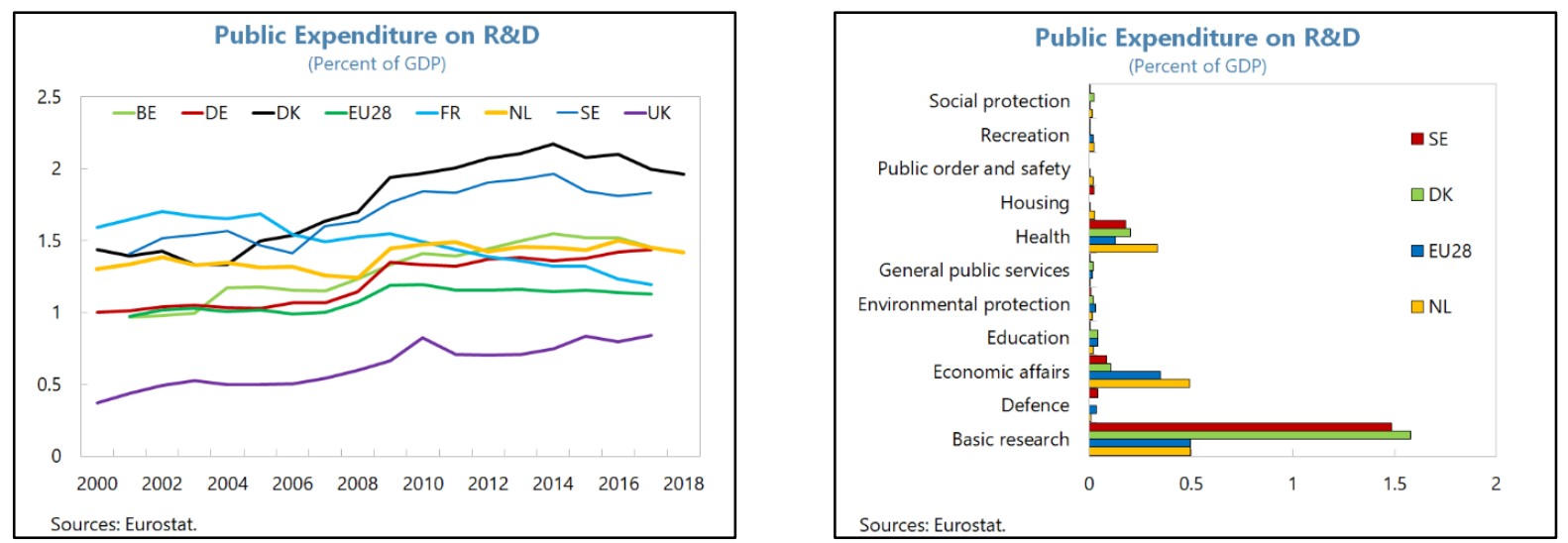

\footnotetext{
${ }^{9}$ R\&D spending on economic affairs includes R\&D spending on general economic, commercial, and labor affairs; agriculture, forestry, fishing and hunting; fuel and energy; mining, manufacturing, and construction, transport; communication; other industries; and economic affairs not elsewhere classified.
} 


\section{Third, labor regulations discriminate more severely between regular and} temporary workers than in peer countries. As of 2013, the factors that make the Netherlands regulations on regular workers stricter than in peers include (1) the notification procedures in the case of individual dismissal and (2) the length of the trial period. The factors that make the regulations on temporary workers less strict include (1) unlimited maximum cumulated duration of temporary work agency assignments and (2) no requirement on the authorization or reporting obligations for the set-up of a temporary work agency. Such divergence in the labor regulations for different types of contract can be one of the factors behind the high share of workers in FWA, contributing to the duality of the labor market. As discussed by Aiyar et al. (2019), labor market duality could lead to longer recovery and shorter expansion periods after negative shocks, which can then contribute to lower MFP. ${ }^{10}$ One way to reduce the labor market duality is to establish a structural safety net for all workers including those in FWA, which also allows automatic stabilizers to work properly in the event of economic shocks, including the COVID-19 pandemic.
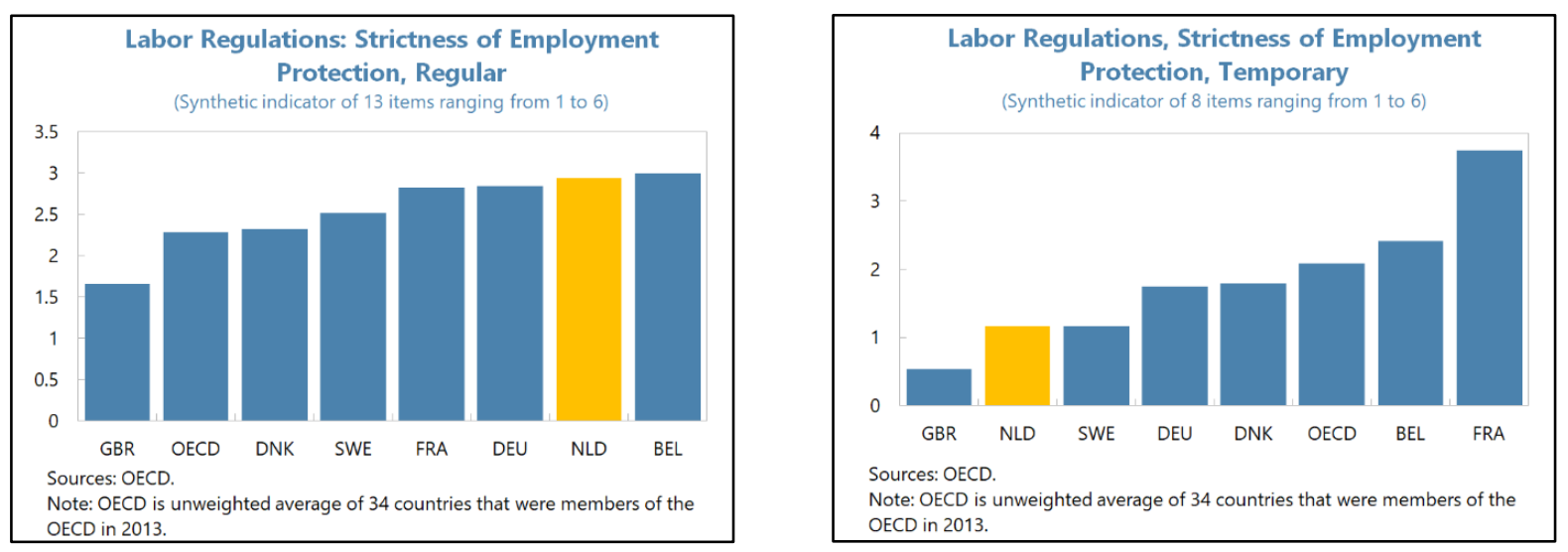

\section{Conclusion}

23. The analysis of productivity growth in the Netherlands suggests that its slowdown is likely to be driven by both exogenous shocks and structural problems. Exogenous shocks, such as the earthquakes and specific policy decisions, have contributed to the shrinkage of high-productivity mining and finance sectors. The structural problems, including the duality of the labor market, skill mismatch, and weak investment, can be addressed, at least in part, by appropriate policy instruments.

\section{The analyses highlight several policy options for sustainable productivity}

growth. Specifically, the Netherlands will benefit from targeted government support to

- education: for sustaining the supply of needed human capital;

\footnotetext{
${ }^{10}$ Duval and Loungani (2019) discuss other consequences of labor market duality.
} 
- $R \& D$ including basic research: for retaining the position as an innovation leader; and

- capital: for facilitating productivity-enhancing investment.

The country could also benefit from reforms to reduce labor market duality by

- lessening the regulations on regular workers: to maintain inclusive and resilient growth; and

- adjusting the regulations on flexible work arrangements: to incentivize both firms and workers to "invest" in raising productivity.

25. The analysis also sheds light on the resource constraints in both labor and capital inputs. The sectors with higher productivity growth, including manufacturing and construction, tend to face the shortage of staff with needed skills. The unemployment rate as of January 2020 was as low as 3 percent. The capital accumulation has been weaker over the last decades, especially in sectors with lower productivity growth. Further policies to boost labor supply and capital accumulation will benefit the growth of the Netherlands. 


\section{Appendix I. Description of Sector Labels}

\begin{tabular}{|l|ll|}
\hline Sector label & Description (Alphabet at the beginning corresponds to NACE Rev. 2) \\
\hline agff & A & Agriculture, forestry and fishing \\
\hline mine & B & Mining and quarrying \\
\hline manu & C & Manufacturing \\
\hline enrg & D & Energy supply \\
\hline watw & E & Water supply and waste management \\
\hline cons & F & Construction \\
\hline trad & G & Wholesale and retail trade \\
\hline tran & H & Transportation and storage \\
\hline acfo & I & Accommodation and food serving \\
\hline info & J & Information and communication \\
\hline fina & K & Financial institutions \\
\hline real & L & Renting, buying, selling real estate \\
\hline obus & M & Other specialised business services \\
\hline adsu & N & Renting and other business support \\
\hline publ & O & Public administration and services \\
\hline educ & P & Education \\
\hline heal & Q & Health and social work activities \\
\hline cult & R & Culture, sports and recreation \\
\hline oser & S & Other service activities \\
\hline hh & T & Activities of households \\
\hline extr & U & Extraterritorial organisations \\
\hline & & \\
\hline
\end{tabular}




\section{REFERENCES}

Aiyar, Shekhar, John Bluedorn, Romain Duval, Davide Furceri, Daniel Garcia-Macia, Yi Ji, Davide Malacrino, Haonan Qu, Jesse Siminitz, and Aleksandra Zdzienicka. 2019. "Strengthening the Euro Area: The Role of National Structural Reforms in Enhancing Resilience." IMF Staff Discussion Note.

Bondt, Hugo de. 2019. "Lagere productiviteit door groei zelfstandigen De samenhang tussen zelfstandigen, flexwerknemers en productiviteit, 2003-2018." CBS.

Bun, Maurice J.G., and Jasper de Winter. 2019. "Measuring Trends and Persistence in Capital and Labor Misallocation." De Netherlandsche Bank Working Paper.

CBS. 2018. Businesses face growing shortage of staff. August. https://www.cbs.nl/en$\mathrm{gb} /$ news/2018/33/businesses-face-growing-shortage-of-staff.

Duval, Romain, and Prakash Loungani. 2019. "Designing Labor Market Institutions in Emerging Market and Developing Economies: Evidence and Policy Options." IMF Staff Discussion Note.

European Commission. 2016. The Netherlands: Mismatch priority occupations. October. Accessed 2020.

https://skillspanorama.cedefop.europa.eu/en/analytical_highlights/netherlandsmismatch-priority-occupations\#_summary.

Grabska, Katarzyna, Leon Bettendorf, Rob Luguinbuhl, Gerdien Meijerink, and Adam Elbourne. 2017. "Productivity Slowdown - Evidence for the Netherlands." $C P B$ Communication.

Jonkers, Wouter. 2019. "De invloed van de toename van het aantal gewerkte uren op de productiviteit." $C B S$.

National Institute for Public Health and the Environment. 2019. "Greenhouse gas emissions in the Netherlands 1990-2017 National Inventory Report 2019."

OECD. 2019. OECD Compendium of Productivity Indicators 2019. OECD Publishing. doi:https://doi.org/10.1787/b2774f97-en. 